\title{
Chemical characterization and antimicrobial activity of essential oils of salvia $\mathrm{L}$. species
}

\author{
Caracterização química e atividade antimicrobiana de óleos essenciais de distintas espécies de salvia $L$. \\ Morgana Karen PIEROZAN ${ }^{1,2}$, Gabriel Fernandes PAULETTI ${ }^{2}$, Luciana ROTA², \\ Ana Cristina Atti dos SANTOS ${ }^{2}$, Lindomar Alberto LERIN ${ }^{1}$, Marco DI LUCCIO ${ }^{1}$, Altemir José MOSSI ${ }^{1}$, \\ Luciana ATTI-SERAFINI², Rogério Luis CANSIAN ${ }^{1}$, José VLADIMIR OLIVEIRA ${ }^{1 *}$
}

\begin{abstract}
In this work, the essential oils of S. officinalis, S. sclarea, S. lavandulifolia and S. triloba were chemically analyzed by gas chromatography coupled to a mass spectrometry detector (GC/MSD), and their antimicrobial activity was tested against 10 microorganisms using the disk diffusion method and the Minimum Inhibitory Concentration (MIC) technique. The following major compounds were identified in the essential oils: $\alpha$ - and $\beta$-thujone, camphor and 1,8-cineole, except in S. sclarea, where linalool, linalyl acetate and $\alpha$-terpineol were the major constituents. The antimicrobial activity showed significant differences $(\mathrm{p}<0.05)$ only when obtained by the MIC method. Gram-positive microorganisms presented larger sensitivity for the essential oils. The lowest MIC was observed when Staphylococcus aureus was exposed to $2.31 \mathrm{mg}$. $\mathrm{mL}^{-1}$ of S. lavandulifolia essential oil, while the highest MIC value was obtained when Shigella flexneri was exposed to $9.25 \mathrm{mg} . \mathrm{mL}^{-1}$ of the same essential oil, thus demonstrating that this essential oil may be effective as a bacteriostatic agent against Gram-positive microorganisms. Keywords: Salvia; essential oils; antimicrobial activity; chemical characterization.
\end{abstract}

\section{Resumo}

Neste trabalho os óleos essenciais de S. officinalis, S. sclarea, S. lavandulifolia e Salvia sp. foram analisados quimicamente por cromatografia gasosa acoplada a espectrômetro de massas. A atividade antimicrobiana dos óleos essenciais foi testada contra 10 microrganismos utilizando o método de difusão em discos e através da determinação da Concentração Inibitória Mínima (CIM). Cânfora, $\alpha$ - e $\beta$-thujone e 1,8-cineol foram os compostos majoritários identificados na maioria dos óleos essenciais, exceto para $S$. sclarea, em que linalol, acetato de linalil e a-terpineol foram os compostos majoritários identificados. As atividades antimicrobianas apresentaram diferenças significativas $(\mathrm{p}<0,05)$ somente quando obtidas pelo método CIM. Microorganismos gram-positivos apresentaram grande sensibilidade para os óleos essenciais. A menor CIM foi observada para o Staphylococcus aureus quando exposto a $2,31 \mathrm{mg} \cdot \mathrm{mL}^{-1}$ de óleo essencial de $S$. lavandulifolia, enquanto que a maior CIM foi observada para Shigella flexneri exposta a 9,25 mg.mL ${ }^{-1}$ do mesmo óleo essencial, provando que este óleo constitui-se em um eficiente agente bacteriostático contra microrganismos gram-positivos.

Palavras-chave: Salvia; óleos essenciais; atividade antimicrobiana; caracterização química.

\section{Introduction}

Numerous investigations have been recently reported dealing with chemical composition, biological properties, and possible applications of essential oils, which may be a source of natural products with economical importance for the food, pharmaceutical, and cosmetic industry.

Essentials oils are in fact complex mixtures of volatile substances, insoluble in water and soluble in organic solvents, which contribute to their characterization and isolation. They may contain a mixture of terpenes, monoterpenes, sesquiterpenes, or even diterpenes, low molecular weight aliphatic hydrocarbons (linear, branched, saturated and unsaturated), acids, alcohols, aldehydes, acyclic esters or lactones and exceptionally nitrogen and sulphur compounds, cumarines, and homologous of phenylpropanes (VELICKOVIC et al., 2002; AVATO et al., 2005).
Essential oils extracted from vegetable matrices have been considered as growth inhibitors of food and human pathogens such as Escherichia coli, Staphylococcus sp., Bacillus sp., Streptococcus sp., Salmonella sp., Mycobacterium sp., Vibrio vulnificus, among others.

Among several aromatic plants with antimicrobial activity, those of the family Lamiaceae, such as Origanum vulgare (oregano), Thymus vulgaris (thyme), Rosmarinus officinalis (rosemary), Mentha piperita (mint), and Salvia officinalis (sage) are prominent. The genus Salvia L. shows about 900 species mainly dispersed in the area of Mediterranean, Southeast Africa, and Central and South America. It is cultivated for culinary, medicinal, and ornamental purposes. Although Salvia is not originally from Brazil, some species have been well adapted, especially in Southern Brazil. They are extensively used by

Departamento de Engenharia de Alimentos, Universidade Regional Integrada - URI, Campus de Erechim, Av. Sete de Setembro, 1621, Erechim, RS, CEP 99700-000, Brazil, E-mail: vladimir@uricer.edu.br

${ }^{2}$ Institute of Biotechnology, Universidade de Caxias do Sul - UCS, Rua Francisco Getúlio Vargas, 1130, CEP 95070-560, Caxias do Sul - RS, Brasil, Caxias do Sul, RS, Brazil

${ }^{*}$ A quem a correspondência deve ser enviada 
popular medicine and many pharmacological studies intended to identify the compounds responsible for their therapeutic effects (KIM; MARSHALL; WEI, 1995; EVANS, 2002; SERAFINI et al., 2002; RADULESCU; CHILIMENT; OPREA, 2004; AVATO et al., 2005).

The chemical characterization and assessment of antimicrobial activity of essential oils of species of the gender Salvia, especially of $S$. officinalis, are documented in some studies. Its antimicrobial activity against several microorganisms has been recognized for decades and has been attributed to the presence of some major compounds in the essential oil like 1,8-cineole, $\beta$-thujone, camphor, borneol and p-cymene, among others (JASSEN; SCHEFFER; BAERHEIM, 1987; SERAFINI et al., 2002; TEPE et al., 2004).

Although the ability of some sage species to biosynthesize substances is of interest to food and pharmaceutical industry, to our knowledge, almost all studies available in the literature are restricted to only one of the species $S$. officinalis of the genus Salvia. Also, information on the performance comparison of essential oils is not available in the literature. In this context, the aim of this work is to report the chemical composition and antimicrobial activity of S. officinalis, S. sclarea, S. lavandulifolia and S. triloba essential oils against a variety of microorganisms.

\section{Material and methods}

\subsection{Materials}

The species S. officinalis 1, S. officinalis 2, S. lavandulifolia, $S$. sclarea and S. triloba were kindly provided by Feltrin (Farroupilha, RS, Brazil), by the Center of Investigation and Food Technology of Aragón (CITA, Spain), and by the Institute of Biotechnology of the University of Caxias do Sul (RS, Brazil). The populations were reproduced from cuttings and seeds and cultivated under agronomic field conditions in Erechim, RS, Brazil.

\subsection{Experimental procedure}

\section{Extraction of the essential oil}

The essential oil was obtained from the aerial flowered part of the plants by hydro-distillation using a glass Clevenger apparatus (FARMACOPÉIA, 1997). Approximately $50 \mathrm{~g}$ of homogenized sample from 10 plants was submitted to hydrodistillation by 1 hour. After the extraction of the essential oil, $0.1 \mathrm{~g}$ anhydrous sodium sulfate was added and the samples were preserved in amber flasks at $4 \mathrm{~L}^{\circ} \mathrm{C}$.

\section{Sample analyses}

The chemical characterization of the extracts was carried out with a Hewlett Packard gas chromatograph with flame ionization detector (HP-6890 Serialize), column HP-Innowax (30 $\mathrm{m} \times 320 \mu \mathrm{m}, 0.50 \mu \mathrm{m}$ film thickness), column temperature at $40^{\circ} \mathrm{C}$ for $8 \mathrm{~min}$, followed by a first temperature increase to $180^{\circ} \mathrm{C}$ at $3{ }^{\circ} \mathrm{C} / \mathrm{min}$, then from 180 to $230^{\circ} \mathrm{C}$ at $20^{\circ} \mathrm{C} / \mathrm{min}$, and held for $20 \mathrm{~min}$ at $230^{\circ} \mathrm{C}$. The injector and detector temperatures were both set at $250^{\circ} \mathrm{C}$, and split ratio at 1:50. Hydrogen was used as carrier gas at $34 \mathrm{kPa}$. The injection volume was $1 \mu \mathrm{L}$ of a sample of the essential oil diluted in n-hexane (1:10).

Gas chromatography with mass spectrometer detector analysis was also carried out using a Hewlett Packard 6890/ MSD5973, equipped with software HP-Chemstation and mass spectra library Wiley 275. A capillary column of fused silica was used (HP-Innowax, $30 \mathrm{~m} \times 250 \mu \mathrm{m}, 0.50 \mu \mathrm{m}$ film thickness). The temperature program was the same used in CG-FID. The interface was set at $280^{\circ} \mathrm{C}$, split ratio $1: 100$, carrier gas was Helium (56 kPa), flow rate: $1.0 \mathrm{~mL} /$ minuto, energy of ionization $70 \mathrm{eV}$. The injection volume was $0.4 \mu \mathrm{L}$ of a sample of the essential oil diluted in $\mathrm{n}$-hexane (1:10).

\section{Antimicrobial activity}

\section{Bacterial strains}

The bacterial strains used to evaluate the antimicrobial activity of the essential oils were Bacillus subtilis ATCC 6633, Enterococcus faecalis ATCC 19433, Micrococcus luteus ATCC 10240, Staphylococcus aureus ATCC 6538, Streptococcus mutans ATCC 25175, Escherichia coli ATCC 25922, Klebsiella pneumoniae ATCC 13883, Salmonella choleraesuis ATCC 10708, Serratia marcescens ATCC 13880, and Shigella flexneri ATCC 12022.

\section{Maintenance of strains}

The selected bacteria were previously cultivated in test tubes with $10 \mathrm{~mL}$ of liquid medium LB - Luria Bentani (tryptone 10 g.L. $\mathrm{L}^{-1}$; yeast extract 5 g.L $\mathrm{L}^{-1}$; sodium chloride 5 g.L $\mathrm{L}^{-1}$ ) for 24 hours at $37^{\circ} \mathrm{C}$. Next, $1.5 \mathrm{~mL}$ glycerol was added, and the total content was distributed in microtubes of $1500 \mu \mathrm{L}$ reaching a final concentration of $13 \%$. The microtubes were stored at $-80{ }^{\circ} \mathrm{C}$.

\section{Antimicrobial screening}

Two different methods were applied for the evaluation of the antimicrobial activity: diffusion in disks and minimum inhibitory concentration (MIC) by the method of serial dilution in microplates (NCCLS, 1997).

\section{Disk diffusion method}

The pre-inoculum preparation was carried out by the cultivation of bacteria in LB medium, at $30^{\circ} \mathrm{C}$ for 24 hours. For the experiments in solid medium, Mueller and Hinton - $\mathrm{MH}$ (Merck) medium was poured into Petri dishes and cooled under sterile conditions. An aliquot of $200 \mu \mathrm{L}$ the pre-inoculum was then added to each Petri dish (approximately $10^{8}$ UFC. $\mathrm{mL}^{-1}$ ) and disks of filter paper (Whatman number 3) with $7 \mathrm{~mm}$ diameter were placed on the solid medium: a disk containing $7.5 \mu \mathrm{L}$ of chloramphenicol, corresponding to $30 \mu \mathrm{g}$, an empty disk (without any compound), used as negative indicator, and four disks with $5.0 \mu \mathrm{L}$ of different essential oils. The Petri dishes were incubated at $36{ }^{\circ} \mathrm{C}$ for 24 hours. The mean diameter of 
inhibition halo was measured for each disk using a caliper rule. All experiments were performed in triplicate.

Determination of minimum inhibitory concentration (MIC)

Minimum inhibitory concentrations (MIC) were determined by the evaluation of growth by optical density. Microtubes were filled with 9.25, 6.93, 4.62, 3.42, 2.87, 2.31, $1.57,0.925$, and $0 \mathrm{mg} \cdot \mathrm{mL}^{-1}$ of essential oil dispersed in $1 \%$ dimethyl sulphoxide (DMSO), $10 \mu \mathrm{L}$ of the pre-inoculum (approximately $10^{8}$ UFC. $\mathrm{mL}^{-1}$ ) and enough culture medium for $1200 \mu \mathrm{L}$ of suspension. After agitation, $100 \mu \mathrm{L}$ of each suspension was poured into the microplate. Samples were analyzed in spectrophotometer at $490 \mathrm{~nm}$ immediately after inoculation $(\mathrm{t}=0 \mathrm{~h})$.

The microtubes with the different concentrations of essential oil were continuously agitated at $30{ }^{\circ} \mathrm{C}$ for 24 hours. After this period, $100 \mu \mathrm{L}$ of each concentration was poured into a microplate and the absorbance was read in a spectrophotometer $(\mathrm{t}=24 \mathrm{~h})$. The MIC was determined based on the difference between the second $(24 \mathrm{~h})$ and first $(0 \mathrm{~h})$ readings of the microplates in relation to the concentrations of the essential oils. All analyses were carried out aseptically in triplicate.

\section{Results and discussion}

\subsection{Chemical composition of the essential oils}

As shown in Table 1, the essential oils of S. officinalis 1 and 2 presented as major compounds, respectively, $\alpha$-thujone (40.37 and $42.97 \%)$, camphor (15.78 and 13.00\%), 1,8-cineole ( 8.07 and $7.54 \%)$, and $\beta$-thujone ( 8.12 and $5.86 \%)$ and $\beta$-pinene (5.06 and 3.27\%) of a total of 96.62 and $90.38 \%$ of the identified compounds. The other compounds were identified in trace concentrations. For the case of S. sclarea essential oil, the major compounds found were linalol, linalyl acetate, and $\alpha$-terpineol, which also corroborate literature data (BARATTA et al., 1998a; ALQUEZAR, 2003; KALEMBA; KUNICKA, 2003; BAGAMBOULA et al., 2004).

The main oil components (90.22\%) of S. lavandulifolia were $\beta$-thujone (19.96\%), camphor (18.97\%), $\alpha$-thujone $(18.95 \%)$, 1,8 -cineole $(8.13 \%)$, and $\beta$-pinene $(3,96 \%)$. Savelev et al. (SAVELEV et al., 2003) also reported borneol, $\alpha$-pinene, bornyl acetate, linalool, and caryophyllene oxide as main compounds in this species. However, in the present work, these compounds were found only in small concentrations of $1.21 \%, 0.43 \%$, and traces $(\mathrm{Tr})$, respectively. Linalool was found in a concentration below $0.01 \%$ and caryophyllene oxide was not detected (ND). Alquezar (2003) did not verify the presence of $\alpha$ and $\beta$-thujone in the oil of $S$. lavandulifolia, while the concentration of 1,8-cineole found by the author was similar to that observed in the present work.

The essential oil of S. sclarea was the only species that showed a different composition, linalool (29.36\%), linalyl acetate (18.35\%), and $\alpha$-terpineol (11.18\%) of all identified peaks of
$81.58 \%$ with observed low concentrations of thujones, camphor, and 1,8-cineole. These results agree with those reported by Foray et al. (1999) and Peana; Moretti; Juliano (1999).

Salvia triloba essential exhibited the same major compounds, although in different concentrations: $22.39 \%$ of a-thujone, $9.60 \%$ of 1,8 -cineol, $9.30 \%$ of $\beta$-pinene, $7.60 \%$ of camphor, $6.71 \%$ of borneol, $5.17 \%$ of $\alpha$-humulene, $5.00 \%$ of $\gamma$-gurjunene, and $3.60 \%$ of $\beta$-thujone of a total of $83.22 \%$ identified compounds. This chemical profile agrees qualitatively with the compounds reported by different authors for S. officinalis oils (SERAFINI; BARROS; AZEVEDO, 2001; VELICKOVIC et al., 2002; AVATO et al., 2005; DELAMARE et al., 2007). SAYED et al. (2001) found1,8-cineol as the major component of Salvia triloba (concentration higher than $60 \%$ ) and smaller amounts of $\alpha$ and $\beta$-thujone.

The composition of the essential oil of Salvia species, as it usually happens with other medicinal and aromatic plants, is highly influenced by genetic and environmental factors. This composition could vary according to the cultivation area, species, age of the plant, propagation form, methods of drying, and extraction of the essential oil, as well as ecological and genetic factors of the plant (CHANG; CHEN; CHAN, 2001; BAGAMBOULA et al., 2004; DELAMARE et al., 2007).

\subsection{Antimicrobial activity}

\section{Disk diffusion method}

This method proved that almost all tested bacteria were susceptible to the essential oils of the studied species of sage although the mean inhibition halos were smaller than those obtained with the antibiotic (chloramphenicol) and no significant difference $(\mathrm{p}<0.05)$ was observed between the results. As presented in Table 2, Serratia marcescens and Enterococcus faecalis were not inhibited by the essential oil of the Salvia triloba.

These results suggest that this evaluation technique can be used as a preliminary step since it is a recognized method and can determine the sensitivity of many microorganisms to certain pharmaceuticals producing semi-quantitative results. On the other hand, some authors affirm that the results obtained with this method are only qualitative and not always reproducible (JANSSEN; SCHEFFER; BAERHEIM, 1987).

The difficulties found in this method are probably related to the volatile nature of the components of the essential oils, which may evaporate during inoculation and incubation. The different abilities of dispersion of the different oils in the culture medium may also contribute to inaccuracies. Therefore, the physicochemical properties of the essential oils will determine their viability as antimicrobial making their evaluation particularly difficult to standardize. However, this remains the most common technique used for the evaluation of antibacterial and antifungal ability of essential oils due to its simplicity and small amounts of sample required (JANSSEN; SCHEFFER; BAERHEIM, 1987; KALEMBA; KUNICKA, 2003). 
Table 1. Volatile compounds identified in the essential oil of Salvia species.

\begin{tabular}{|c|c|c|c|c|c|}
\hline \multirow{2}{*}{ Compound } & \multicolumn{5}{|c|}{ Composition (peak area \%) } \\
\hline & S. officinalis 1 & S. officinalis 2 & S. lavandulifolia & S. sclarea & S. triloba \\
\hline a-thujone & $40.37 \pm 1.0$ & $42.97 \pm 1.3$ & $18.95 \pm 7.7$ & $0.45 \pm 0.1$ & $22.39 \pm 1.1$ \\
\hline$\beta$-thujone & $8.12 \pm 1.1$ & $5.86 \pm 0.7$ & $19.96 \pm 3.5$ & $0.12 \pm 0.01$ & $3.60 \pm 0.1$ \\
\hline Camphor & $15.78 \pm 0.1$ & $13.00 \pm 1.6$ & $18.97 \pm 0.3$ & $0.99 \pm 0.1$ & $7.60 \pm 0.7$ \\
\hline 1,8-cineole & $8.07 \pm 0.8$ & $7.54 \pm 0.6$ & $8.13 \pm 0.2$ & $0.40 \pm 0.1$ & $9.60 \pm 0.3$ \\
\hline$\gamma$-gurjunene & $2.93 \pm 0.6$ & $3.32 \pm 0.3$ & $6.15 \pm 0.1$ & $0.36 \pm 0.04$ & $5.00 \pm 0.4$ \\
\hline$\beta$-caryophyllene & $1.37 \pm 0.1$ & $1.37 \pm 0.1$ & $1.62 \pm 0.3$ & $2.03 \pm 0.1$ & $4.00 \pm 0.4$ \\
\hline a-humulene & $2.90 \pm 0.1$ & $2.78 \pm 0.5$ & $3.34 \pm 1.2$ & - & $5.17 \pm 0.1$ \\
\hline$\beta$-pinene & $5.06 \pm 0.4$ & $3.27 \pm 0.4$ & $3.96 \pm 0.1$ & $0.17 \pm 0.04$ & $9.30 \pm 0.07$ \\
\hline Camphene & $4.32 \pm 0.7$ & $3.55 \pm 0.7$ & $2.09 \pm 0.1$ & - & $4.00 \pm 0.2$ \\
\hline Limonene & $1.27 \pm 0.1$ & $1.14 \pm 0.1$ & $1.46 \pm 0.2$ & $0.41 \pm 0.04$ & $1.00 \pm 0.03$ \\
\hline Borneol & $1.55 \pm 0.2$ & $1.72 \pm 0.3$ & $1.21 \pm 0.01$ & - & $6.71 \pm 0.4$ \\
\hline Mircene & $0.97 \pm 0.1$ & $0.85 \pm 0.1$ & $1.05 \pm 0.1$ & $1.73 \pm 0.3$ & $0.76 \pm 0.06$ \\
\hline Sabinene & $2.95 \pm 0.1$ & $2.05 \pm 0.1$ & $2.75 \pm 0.6$ & - & $0.19 \pm 0.03$ \\
\hline a-pinene & $0.72 \pm 0.02$ & $0.80 \pm 0.1$ & $0.43 \pm 0.1$ & Tr. & $3.90 \pm 0.1$ \\
\hline Bornil acetate & $0.24 \pm 0.1$ & $0.16 \pm 0.03$ & Tr. & - & - \\
\hline$\alpha$-terpineol & - & - & - & $11.18 \pm 0.7$ & - \\
\hline caryophyllene oxide & - & - & - & $1.60 \pm 0.2$ & - \\
\hline Geraniol & - & - & - & $4.58 \pm 0.3$ & - \\
\hline Nerol & - & - & - & $1.63 \pm 0.2$ & - \\
\hline Neril acetate & - & - & - & $2.76 \pm 0.03$ & - \\
\hline Linalyl acetate & - & - & - & $18.35 \pm 0.1$ & - \\
\hline Linalool & - & - & - & $29.36 \pm 1.6$ & - \\
\hline Seranil acetate & - & - & - & $5.36 \pm 0.4$ & - \\
\hline Overall & 96.62 & 90.38 & 90.22 & 81.58 & 83.22 \\
\hline
\end{tabular}

Table 2. Antimicrobial activity of essential oils assayed by the disk diffusion method.

\begin{tabular}{|c|c|c|c|c|c|c|}
\hline \multirow[t]{2}{*}{ Microorganisms } & \multicolumn{6}{|c|}{ Average halo (mm) } \\
\hline & \multicolumn{6}{|c|}{ S. } \\
\hline Gram-negative & officinalis 1 & officinalis 2 & lavandulifolia & sclarea & triloba & $A n t^{*}$ \\
\hline Escherichia coli & 8.0 & 7.9 & 10.2 & 9.3 & 10.0 & 24.3 \\
\hline Klebsiella pneumonae & 9.0 & 8.5 & 9.3 & 11.5 & 9.4 & 21.0 \\
\hline Salmonella choleraesuis & 10.3 & 10.0 & 8.7 & 11.7 & 7.5 & 23.0 \\
\hline Serratia marcescens & 9.7 & 9.5 & 9.5 & 9.7 & $\mathrm{NS}^{\dagger}$ & 14.3 \\
\hline Shigella flexneri & 10.0 & 10.0 & 10.0 & 11.0 & 8.5 & 25.0 \\
\hline Average & $9.4^{\mathrm{a}}$ & $9.2^{\mathrm{a}}$ & $9.5^{\mathrm{a}}$ & $10.6^{\mathrm{a}}$ & $8.8^{\mathrm{a}}$ & - \\
\hline \multicolumn{7}{|l|}{ Gram-positive } \\
\hline Bacillus subtilis & 9.0 & 8.5 & 9.0 & 9.0 & 9.0 & 28.0 \\
\hline Enterococcus faecalis & 11.4 & 10.5 & 10.2 & 10.6 & NS & 27.7 \\
\hline Micrococcus luteus & 9.2 & 10.2 & 11.3 & 10.7 & 10.0 & 24.0 \\
\hline Staphylococcus aureus & 9.7 & 9.5 & 10.0 & 11.2 & 9.2 & 22.0 \\
\hline Streptococcus mutans & 8.7 & 8.5 & 8.0 & 8.7 & 8.0 & 33.0 \\
\hline Average & $9.6^{\mathrm{a}}$ & $9.4^{\mathrm{a}}$ & $9.7^{\mathrm{a}}$ & $10.0^{\mathrm{a}}$ & $9.0^{\mathrm{a}}$ & - \\
\hline
\end{tabular}

Different letters mean significant difference at $95 \%$ (Dunnet test $-\mathrm{p}<0.05$ ); ${ }^{\star}$ Ant: Antibiotic - Chloramphenicol $(7.5 \mu \mathrm{L})$, with $5 \mu \mathrm{L}$ in each assay; $\nmid$ not susceptible.

\section{Determination of minimum inhibitory concentration (MIC)}

The comparison of mean optical densities by Duncan test at $5 \%$ (Figure 1) and the comparison of antimicrobial activities between Gram-negatives and Gram-positives (Table 3) show that all microorganisms were susceptible to the essential oils of the investigated sage species. The highest MIC was observed in
Gram-negative bacteria treated with the essential oil of S. triloba (8.32 mg. $\mathrm{mL}^{-1}$ ), while the lowest MIC was obtained for Grampositive bacteria treated with the essential oil of S. lavandulifolia (3.21 mg.mL $\left.\mathrm{mL}^{-1}\right)$.

High MIC values were observed for the bacteria Salmonella choleraesuis, Serratia marcescens and Shigella flexneri treated 
Table 3. Antimicrobial activity assayed by the method of Minimum Inhibitory Concentration (MIC) (mg.mL $\mathrm{mL}^{-1}$ ).

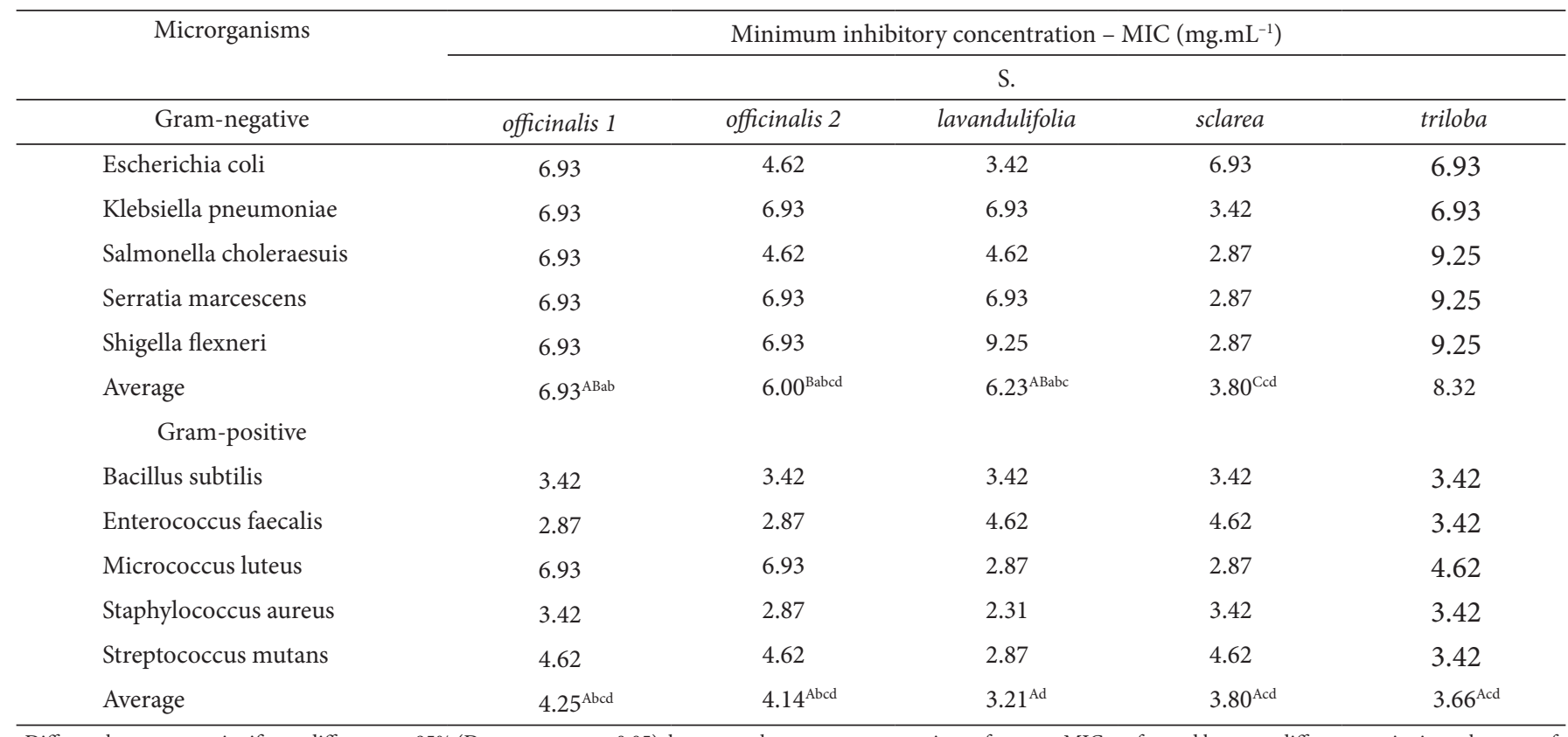

Different letters mean significant difference at 95\% (Dunnet test $-\mathrm{p}<0.05$ ); lower case letters mean comparison of average MIC performed between different species in each group of bacteria and upper case among all groups of bacteria.

with the oil of S. triloba and for S. flexneri when exposed to the oil of S. lavandulifolia at the concentration of $9.25 \mathrm{mg} \cdot \mathrm{mL}^{-1}$ in all cases. The lowest MIC was observed for Staphylococcus aureus treated with the essential oil of S. lavandulifolia (2.31 mg. $\left.\mathrm{mL}^{-1}\right)$.

The results obtained in this work demonstrate that Grampositive bacteria tend to be more sensitive to the essential oils than Gram-negative ones. Some authors report that this is common for essential oils of plants of the Lamiaceae family (SHAPIRO; MEIER; GUGGENHEIM, 1994; HAMMER; CARSON; RILEY, 1999). However, this relation should not be used to define the antimicrobial activity, and thus each case should be carefully evaluated. When observing the results for $S$. officinalis 1, one can note that the Micrococcus luteus presented the highest MIC ( $\left.6.93 \mathrm{mg} \cdot \mathrm{mL}^{-1}\right)$ although being a Gram-positive microorganism. The essential oil of $S$. sclarea presented low MIC for most of the Gram-negative microorganisms, except for Escherichia coli (6.93 mg.mL ${ }^{-1}$ ), which contributed significantly to increase the average values of the group.

The lower susceptibility of Gram-negative bacteria to the essential oils may be explained in terms of diffusion limitations of essential compounds through their external membrane caused by the presence of a hydrophilic barrier. Although this barrier is not totally impermeable, it hinders the transport of macromolecules and hydrophobic components (HELANDER et al., 1998; VELICKOVIC et al., 2002; KALEMBA; KUNICKA, 2003; BAGAMBOULA et al., 2004; TEPE et al., 2004).

The probable mechanisms of action of the essential oils, mainly in Gram-positive microorganisms, is based on the direct

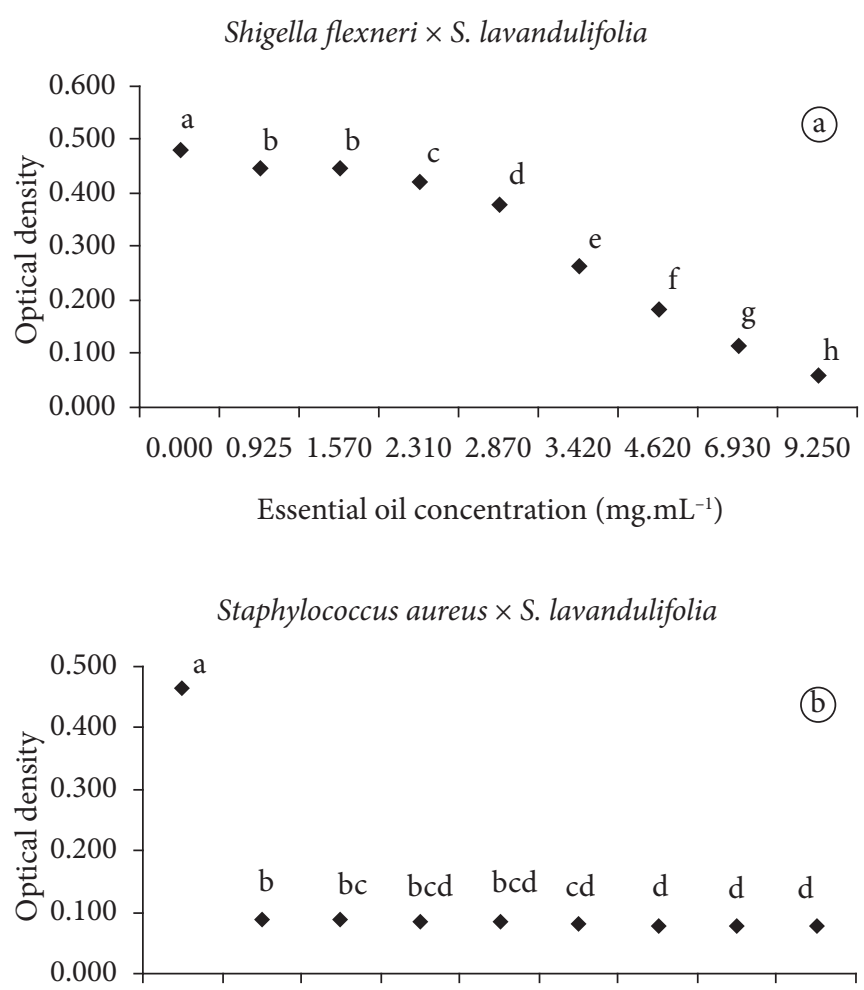

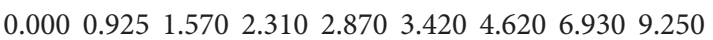

Essential oil concentration (mg.mL $\left.\mathrm{mL}^{-1}\right)$

Figure 1. MIC evaluation of Staphylococcus aureus $\left(2.31 \mathrm{mg} \cdot \mathrm{mL}^{-1}\right)$ and Shigella flexneri $\left(9.25 \mathrm{mg} \cdot \mathrm{mL}^{-1}\right)$ in relation to the essential oil of $S$. lavandulifolia. Averages followed by the same superscript do not differ significantly (Tukey test $-\mathrm{p}<0.05$ ). 
contact of their hydrophobic compounds with the phospholipids of the cellular membrane, which might cause the structural damage or complete rupture of the cellular membranes, losses of nutrients, chemostatic control, and interference in the respiration system. They can also prevent the contact of human cells or food surfaces with the hydrophilic cells of growing microorganisms (SVOBODA; DEANS, 1995; BARATTA et al., 1998a; BARATTA et al., 1998b; COX et al., 2000; KALEMBA; KUNICKA, 2003; BAGAMBOULA et al., 2004).

The MIC observed for Bacillus subtillis was $3.42 \mathrm{mg} \cdot \mathrm{ml}^{-1}$ for the essential oils of $S$. officinalis 1 and 2, a value greater than that reported by Delamare et al. (2007), $0.4 \mathrm{mg} \cdot \mathrm{ml}^{-1}$. For Staphylococcus aureus the value found in this work, $3.42 \mathrm{mg} \cdot \mathrm{ml}^{-1}$, is lower than that of literature (DELAMARE et al., 2007), $5.0 \mathrm{mg} \cdot \mathrm{ml}^{-1}$. The following MIC values have been reported in the literature (HAMMER; CARSON; RILEY, 1999) when using S. officinalis for the microorganisms Enterococcus faecalis, Escherichia coli, Klebsiella pneumoniae, Serratia marcescens and Staphylococcus aureus: 20, 5, 20, 1.0 and $1.0 \mathrm{mg} \cdot \mathrm{ml}^{-1}$, respectively.

Using the essential oil of Salvia sclarea, a MIC of $3.42 \mathrm{mg} \cdot \mathrm{ml}^{-1}$ was observed for Staphylococcus aureus and $6.93 \mathrm{mg} \cdot \mathrm{ml}^{-1}$ for Escherichia coli. These results are higher than those found by Peana; Moretti; Juliano (1999) that reported that the same microorganisms were inhibited in concentrations from 0.25 to $1 \mathrm{mg} \cdot \mathrm{ml}^{-1}$. Hammer; Carson; Riley (1999) showed that the essential oil of S. sclarea presented MIC above $20 \mathrm{mg} \cdot \mathrm{ml}^{-1}$ when tested on Enterococcus faecalis, Escherichia coli, Klebsiella pneumoniae, Serratia marcescens, and Staphylococcus aureus.

Some MIC values found in the present investigation were lower than those usually found in the literature indicating a probable connection with the fact that the suspensions used to determine the MIC were maintained under agitation for $24 \mathrm{~h}$, increasing the contact surface between the essential oil and the microorganism.

Comparing these results with those obtained by the disk diffusion method, it should be noticed that the relation between the results is not always absolute. However, both methods showed high sensitivity to the Gram-positive bacteria, suggesting the possibility of using the disk diffusion method as an initial evaluation of the potential antimicrobial activity of the essential oils. However, this method should be used with caution due to factors involved in such evaluations.

The qualitative and quantitative chemical differences did not present any relation with the antimicrobial activity, indicating that the synergism of different compounds is most probably related to this activity than the presence of some specific compounds. The synergism among the major and minor compounds should be taken into account since they increase the effect of the antimicrobial activity of the essential oils (SAVELEV et al., 2003; DELAMARE et al., 2007). In contrast, some authors attribute the activity of the essential oils of species of sage to certain chemical compounds, such as 1,8-cineole, camphor, $\alpha$ - and $\beta$-thujone, borneol, and p-cymene, among others (JALSENJAK; PELJNAJK; KUSTRAK, 1987; JANSSEN; SCHEFFER; BAERHEIM, 1987; RADULESCU; CHILIMENT; OPREA, 2004; TEPE et al., 2004). The findings of this work demonstrate that the essential oil of S. sclarea has greater antimicrobial action against the Gram-negative bacteria than the other essential oils tested.

\section{Conclusions}

The essential oils of S. officinalis, S. sclarea, S. lavandulifolia and $S$. triloba were chemically analyzed and their antimicrobial activity was determined. Regarding the chemical analysis, the major compounds identified were $\alpha-$ and $\beta$-thujone, camphor, and 1,8-cineole, except for $S$. sclarea (linalool, linalyl acetate and $\alpha$-terpineol). It was observed that Gram-positive microorganisms presented larger sensitivity for the essential oils. The lowest MIC was observed when Staphylococcus aureus was exposed to $2.31 \mathrm{mg} \cdot \mathrm{ml}^{-1}$ of S. lavandulifolia essential oil, while the highest MIC value was obtained when Shigella flexneri was exposed to $9.25 \mathrm{mg} \cdot \mathrm{ml}^{-1}$ of the same essential oil. The present investigation demonstrates that these essential oils may be effective as bacteriostatic agents against Gram-positive microorganisms.

\section{Acknowledgements}

The authors are grateful to the University of Caxias do Sul, URI-Campus of Erechim, FAPERGS, and SCT/RS for the financial support and scholarships.

\section{References}

ALQUEZAR, J. B. Investigación y experimentación de plantas aromáticas e medicinales en Aragón. Cultivo, transformación y analítica. Espanha: Governo de Aragón, 2003. 262 p.

AVATO, P. et al. Glandular hairs and essential oils in micropropagated plants of Salvia officinalis L. Plant Science, v. 169, n. 1, p. 29-36, 2005.

BAGAMBOULA, C. F. et al. Antimicrobial and antioxidative activities of the essential oils and methanol extracts of S. cryptantha (Montbret et Aucher ex Benth.) and S. multicaulis (Vahl.). Food Chemistry, v. 84 , n. 4 , p. 519-525, 2004.

BARATTA, M. T. et al. Chemical composition, antimicrobial and antioxidative activity of laurel, sage, rosemary, oregano and coriander essential oils. Journal of Essential Oil Research, v. 10, n. 6, p. 618-627, 1998a.

BARATTA, M. T. et al. Antimicrobial and antioxidant properties of some commercial essential oils. Flavour \& Fragance, v. 13, n. 4, p. 235-244, 1998b.

CHANG, S. T.; CHEN, P. F.; CHAN, S. C. Antibacterial activity of leaf essential oils and their constituents from Cinnamonum osmophleum. Journal of Ethnopharmacology, v. 77, n. 1, p. 123-127, 2001.

COX, S. D. et al. Them mode of antimicrobial action of the essential oils of Melaleuca alternifolia (tea tree oil). Journal of Applied Microbiology, v. 88, n. 1, p. 170-175, 2000.

DELAMARE, A. P. L. et al. Antibacterial activity of essential oils of Salvia officinalis L. and Salvia triloba L. cultivated in South Brazil. Food Chemistry, v. 100, n. 2, p. 603-608, 2007.

EVANS, W. C. Pharmacognosy. 15 ed. Toronto: W. B. Saunders, 2002. 
FARMACOPÉIA BRASILEIRA. Métodos de Farmacognosia. 4 ed. São Paulo: Atheneu Editora São Paulo Ltda, 1997. (Parte 1, Fascículo 1).

FORAY, L. et al. In vitro cytotoxic activity of three essential oils from Salvia species. Journal of Essential Oil Research, v. 11, n. 1, p. 522-526, 1999.

HAMMER, K. A.; CARSON, C. F.; RILEY, T. V. Antimicrobial activity of essential oils and other plant extracts. Journal of Applied Microbiology, v. 86, n. 6, p. 985-990, 1999.

HELANDER, I. M. et al. Characterization of the Action of Selected Essential Oil Components on Gram-Negative Bacteria. Journal of Agricultural and Food Chemistry, v. 46, n. 9, p. 3590-3595, 1998.

JALSENJAK, V.; PELJNAJK, S.; KUSTRAK, D. Microcapsules of sage oil, essential oils content and antimicrobial activity. Pharmazie, v. 42, n. 6, p. 419-420, 1987.

JANSSEN, A. M.; SCHEFFER, J. J.; BAERHEIM, S. A. Antimicrobials activities of essential oils. Pharmaceutics Week lad (Scientific Edition), v. 9, n. 4, p. 193-197, 1987.

KALEMBA, D.; KUNICKA, A. Antibacterial and Antifungal Properties of Essential Oils. Current Medicinal Chemistry, v. 10, n. 10, p. 813-829, 2003.

KIM, J.; MARSHALL, M. R.; WEI, C. Antibacterial Activity of Some Essential Oil Components against Five Foodborne Pathogens. Journal of Agricultural and Food Chemistry, v. 43, n. 11, p. 2839-2845, 1995.

NATIONAL COMMITTEE FOR CLINICAL LABORATORY STANDARDS - NCCLS. Performance standards for antimicrobial disk susceptibility test. 6 ed. Wayne PA, 1997. Approved Standard M2-A6.

PEANA, A. T.; MORETTI, M. D.; JULIANO, C. Chemical Composition and Antimicrobial Action of the Essential Oils of Salvia desoleana and S. sclarea. Planta Medica, v. 65, n. 8, p. 752-754, 1999.
RADUlESCU, V.; CHILIMENT, S.; OPREA, E. Capillary gas chromatography-mass spectrometry of volatile and semi-volatile compounds of Salvia officinalis. Journal of Chromatography A, v. 1027, n. 1-2, p. 121-126, 2004.

SAVELEV, S. et al. Synergistic and antagonistic interactions of anticholinesterase terpenoides in Salvia lavandulaefolia essential oil. Pharmacology, Biochemistry and Behavior, v. 75, n. 3, p. 661-668, 2003.

SAYED, N. H. E. et al. Constituents from Salvia triloba. Fitoterapia, v. 72, n. 7, p. 850-853, 2001.

SERAFINI, L. A.; BARROS, N. M.; AZEVEDO, J. L. Biotecnologia na agricultura e na agroindústria. Guaíba: Agropecuária, 2001. Cap. 9, p. 333-337.

SERAFINI, L. A. et al. Extrações e aplicações de óleos essenciais de plantas aromáticas e medicinais. Caxias do Sul: EDUCS, 2002.

SHAPIRO, S.; MEIER, A.; GUGGENHEIM, B. The antimicrobial activity of essential oils and essential oil components towards oral bacteria. Oral Microbiology and Immunology, v. 9, n. 4, p. 202-208, 1994.

SVOBODA, K. P.; DEANS, S. G. Biological activities of essential oils from selected aromatic plants. Acta Horticulture, v. 390, n. 1, p. 203-209, 1995.

TEPE, B. et al. Antimicrobial and antioxidative activities of the essential oils and methanol extracts of S. cryptantha (Montbret et Aucher ex Benth.) S. multicaulis (Vahl.). Food Chemistry, v. 84, n. 4 , p. 519-525, 2004.

VELICKOVIC, D. T. et al. Chemical composition and antimicrobial action of the ethanol extracts of $S$. pratensis L. S. glutinosa L. S. aethiopis L. Journal Serbia Chemical Society, v. 67, n. 10, p. 639-646, 2002. 